\title{
BUDŻET OBYWATELSKI, OBOWIĄZEK SPORZĄDZANIA I UTRWALANIA PISEMNEGO WYKAZU GŁOSOWAŃ RADNYCH ORAZ OBOWIAZZEK TRANSMITOWANIA I UTRWALANIA OBRAD ORGANÓW STANOWIACYCH I KONTROLNYCH JAKO PRZEJAWY ZWIĘKSZENIA UDZIAŁU CZŁONKÓW WSPÓLNOT SAMORZĄDOWYCH W PROCESIE FUNKCJONOWANIA I KONTROLOWANIA ORGANÓW SAMORZĄDU TERYTORIALNEGO
}

\begin{abstract}
Abstrakt: Jednym z celów nowelizacji samorządowych ustaw ustrojowych wprowadzonej ustawą z dnia 11 stycznia 2018 roku było zwiększenie udziału obywateli (członków wspólnot samorządowych) w procesie funkcjonowania i kontrolowania organów jednostek samorządu terytorialnego. W artykule przeprowadzono analizę dodanych do ustaw samorządowych przepisów ustanawiających instytucje budżetu obywatelskiego, obowiązku sporządzania i utrwalania pisemnego wykazu głosowań radnych, obowiązku transmitowania i utrwalania obrad organów stanowiących i kontrolnych, a także dokonano próby oceny realizacji za pomocą tych instytucji celu postawionego przez twórców nowelizacji.
\end{abstract}

Słowa kluczowe: budżet obywatelski, pisemny wykaz głosowań radnych, transmitowanie i utrwalanie obrad, proces funkcjonowania i kontrolowania organów samorządu terytorialnego

\section{UWAGI WPROWADZAJĄCE}

Ustawą z dnia 11 stycznia 2018 roku o zmianie niektórych ustaw w celu zwiększenia udziału obywateli w procesie wybierania, funkcjonowania i kontrolowania niektórych organów publicznych ${ }^{1}$ dokonano licznych zmian w ustawie o samo-

1 Dz.U. poz. 130 (dalej: ustawa nowelizująca). 
rządzie gminnym ${ }^{2}, \mathrm{w}$ ustawie o samorządzie powiatowym ${ }^{3}$ oraz w ustawie o samorządzie województwa ${ }^{4}$ (dalej łącznie: samorządowe ustawy ustrojowe, ustawy ustrojowe lub ustawy samorządowe). W zamyśle twórców nowelizacji wiele przedmiotowych zmian miało służyć, na co wskazuje już tytuł ustawy nowelizującej, zwiększeniu udziału obywateli, w szczególności członków poszczególnych wspólnot samorządowych, w funkcjonowaniu tych wspólnot, w wykonywaniu zadań publicznych przez ich organy. W związku z tym na gruncie zmian wprowadzonych przepisami ustawy nowelizującej można zauważyć przesunięcie akcentów demokracji przedstawicielskiej na rzecz form sprawowania demokracji bezpośredniej ${ }^{5}$.

Do instytucji zmierzających na podstawie nowelizacji w sposób bezpośredni do zwiększenia udziału członków wspólnot samorządowych w funkcjonowaniu i kontrolowaniu organów samorządu terytorialnego zaliczyć można instytucję budżetu obywatelskiego, utrwalanie imiennego wykazu głosowań radnych, transmitowanie i utrwalanie obrad organów stanowiących i kontrolnych jednostek samorządu terytorialnego (dalej: j.s.t.), a także obligatoryjne powoływanie przez organ stanowiący i kontrolny każdej j.s.t. komisji skarg, wniosków i petycji, udział mieszkańców j.s.t. w debacie nad raportem o stanie tej jednostki oraz możliwość wystąpienia przez mieszkańców jednostki z inicjatywą uchwałodawczą. Natomiast — również przewidziane w przepisach ustawy nowelizującej — obowiązek podawania do wiadomości publicznej treści interpelacji i zapytań kierowanych przez radnych organów stanowiących i kontrolnych do organów wykonawczych oraz odpowiedzi na nie ${ }^{6}$, przyznanie radnym uprawnień do uzyskiwania informacji i materiałów, wstępu do pomieszczeń, w których takie informacje i materiały się znajdują, wglądu w działalność urzędu gminy, starostwa powiatowego lub urzędu marszałkowskiego, spółek z udziałem j.s.t., spółek z udziałem samorządowych osób prawnych, samorządowych osób prawnych oraz samorządowych jednostek organizacyjnych, z zachowaniem przepisów o tajemnicy prawnie chronionej ${ }^{7}$, należy traktować jako odnoszące się do tego celu w sposób jedynie pośredni.

Celem autorki artykułu jest dokonanie analizy wybranych zmian wprowadzonych do samorządowych ustaw ustrojowych, służących w sposób bezpośredni zwiększeniu udziału członków wspólnot samorządowych w procesie funkcjonowania i kontrolowania organów samorządu terytorialnego, a także próba oceny

2 Ustawa z dnia 8 marca 1990 roku o samorządzie gminnym, tekst jedn. Dz.U. z 2020 r. poz. 713 (dalej: u.s.g.).

${ }^{3}$ Ustawa z dnia 5 czerwca 1998 roku o samorządzie powiatowym, tekst jedn. Dz.U. z 2020 r. poz. 920 (dalej: u.s.p.).

${ }^{4}$ Ustawa z dnia 5 czerwca 1998 roku o samorządzie województwa, tekst jedn. Dz.U. z 2019 r. poz. 512 (dalej: u.s.w.).

5 Por. C. Martysz, Komentarz do art. 28aa ustawy o samorzadzie gminnym, [w:] Ustawa o samorządzie gminnym. Komentarz, red. B. Dolnicki, Warszawa 2018, s. 537; zob. też A. Dąmbska, Mieszkańcy na tym nie skorzystaja, ,Dziennik Gazeta Prawna” 2018, nr 44.

${ }^{6}$ Zob. art. 24 ust. 7 u.s.g., art. 21 ust. 13 u.s.p. i art. 23 ust. 9 u.s.w.

7 Zob. art. 24 ust. 2 u.s.g., art. 21 ust. 2 a u.s.p. i art. 23 ust. 3 b u.s.w. 
stopnia realizacji tego celu w świetle stosownych przepisów ustawy nowelizującej, zmieniającej samorządowe ustawy ustrojowe.

Ze względu na obszerny zakres nowelizacji objęty materią artykułu w jego treści ograniczono się wyłącznie do analizy tworzenia budżetu obywatelskiego w j.s.t., obowiązku sporządzania i utrwalania pisemnego wykazu głosowań radnych jako szczególnego przypadku głosowania imiennego oraz obowiązku transmitowania i utrwalania obrad organów stanowiących i kontrolnych j.s.t. Kwestie powoływania przez te organy obligatoryjnej komisji skarg, wniosków i petycji, udziału mieszkańców j.s.t. w debacie nad stanem tej jednostki, a także możliwości wystąpienia przez mieszkańców z inicjatywą uchwałodawczą będą natomiast materią rozważań odrębnego opracowania.

\section{BUDŻET OBYWATELSKI}

Pierwszym rozwiązaniem wprowadzonym w toku nowelizacji z 11 stycznia 2018 roku, które można uznać za służące zwiększeniu udziału obywateli, a ściślej mieszkańców j.s.t., w procesie funkcjonowania i kontrolowania organów tych jednostek, w tym wypadku w aspekcie finansowym (budżetowym) jest budżet obywatelski. Instytucja budżetu obywatelskiego jest instytucją demokracji bezpośredniej, która do czasu nowelizacji z 11 stycznia 2018 roku funkcjonowała w polskim systemie samorządu terytorialnego poza regulacją ustawową. Wprowadzając unormowania ustawowe w tym zakresie, ustawodawca zrealizował stawiany w doktrynie postulat uregulowania podstawowych założeń działania tej formy demokracji bezpośredniej ${ }^{8}$.

Budżet obywatelski można zdefiniować w ujęciu funkcjonalnym jako formę współudziału członków społeczności lokalnej w podejmowaniu decyzji o przeznaczeniu pewnej puli środków publicznych ${ }^{9}$. Jako forma współuczestniczenia mieszkańców gminy, dzielnicy, osiedla lub sołectwa, a w świetle przepisów ustawy nowelizującej także powiatu i województwa samorządowego, w projektowaniu lokalnych wydatków zapewnia on mieszkańcom prawo do podejmowania wiążących decyzji co do tworzenia części budżetu i określania jego wydatków ${ }^{10}$. Budżet partycypacyjny polega na przyznaniu mieszkańcom danej wspólnoty możliwości decydowania o przeznaczeniu środków publicznych pochodzących z budżetu danej j.s.t. na realizację zadań publicznych należących do zakresu jej

8 Por. M. Augustyniak, R. Marchaj, Komentarz do art. 5 a ustawy o samorzadzie gminnym, [w:] Ustawa o samorzadzie..., s. 159.

9 D. Sześciło, Uwarunkowania prawne budżetu partycypacyjnego w Polsce, „Finanse Komunalne" 2012, nr 12, s. 15; M. Baraniecki, O swoich pieniadzach decydujemy sami — planowanie partycypacyjne budżetu gminy, [w:] Partycypacja społeczna w samorzadzie terytorialnym, red. B. Dolnicki, Warszawa 2014, s. 574.

10 Por. M. Augustyniak, R. Marchaj, op. cit., s. 160. 
działania, uznanych za istotne przez mieszkańców, mogących podlegać w danym roku budżetowym finansowaniu ze środków publicznych ${ }^{11}$.

W świetle art. $5 \mathrm{a}$ ust. 4 zd. 1 u.s.g., art. 3 d ust. 4 zd. 1 u.s.p. i art. 10a ust. 4 zd. 1 u.s.w. w ramach budżetu obywatelskiego mieszkańcy w bezpośrednim głosowaniu decydują corocznie o części wydatków budżetu — odpowiednio: gminy, powiatu albo województwa. Zadania wybrane przez mieszkańców w ramach budżetu obywatelskiego powinny z mocy prawa zostać uwzględnione w uchwale budżetowej danej j.s.t. W toku prac nad projektem uchwały budżetowej organ stanowiący j.s.t. nie może usuwać lub zmieniać w stopniu istotnym zadań wybranych w ramach budżetu obywatelskiego, co wynika z art. 5a ust. 4 zd. 2 i 3 u.s.g., art. $3 d$ ust. 4 zd. 2 i 3 u.s.p. i z art. 10a ust. 4 zd. 2 i 3 u.s.w.

Podkreślenia wymaga, że użyte przez ustawodawcę sformułowanie dotyczące niemożliwości dokonywania przez organ stanowiący i kontrolny j.s.t. zmian w zakresie zadań wybranych $w$ ramach budżetu obywatelskiego $\mathrm{w}$ istotnym stopniu jest sformułowaniem o charakterze nieostrym, wymagającym interpretacji. Wobec tego w praktyce mogą powstawać problemy w rozróżnieniu wprowadzanych przez organ stanowiący i kontrolny zmian o charakterze nieistotnym i zakazanych przez ustawodawcę zmian o charakterze istotnym odnoszących się do zadań wybranych przez mieszkańców w ramach budżetu obywatelskiego. Takie rozwiązanie prowadzi do niebezpieczeństwa ograniczania zakresu zadań wybranych przez mieszkańców w ramach budżetu obywatelskiego przez organy j.s.t., które w danych warunkach mogą kierować się innymi zamysłami wydatkowania środków publicznych, co w konsekwencji może powodować osłabienie udziału mieszkańców w procesie funkcjonowania j.s.t. poprzez budżet obywatelski. Istnieje bowiem ryzyko, że organ stanowiący i kontrolny j.s.t. będzie wprowadzał znaczące zmiany w stosunku do zadań wybranych przez mieszkańców, traktując je jako dozwolone przecież przez ustawodawcę zmiany o charakterze nieistotnym. Co więcej, może dojść do sytuacji, że nawet organy nadzoru i sądy administracyjne będą napotykały trudności w ustaleniu granicy między zmianami istotnymi a zmianami o charakterze nieistotnym. Osłabienie w ten sposób zaangażowania mieszkańców w funkcjonowanie j.s.t. poprzez instytucję budżetu obywatelskiego potęguje dodatkowo okoliczność, iż budżet obywatelski jest formą konsultacji społecznych, konsultacje społeczne zaś jako forma demokracji bezpośredniej z założenia nie mają charakteru wiążącego dla organów j.s.t. ${ }^{12}$, lecz jedynie charakter opiniodawczy ${ }^{13}$.

11 Por. B. Jaworska-Dębska, Normatywne podstawy społecznego dialogu w samorzadzie terytorialnym, [w:] Prawne problemy samorzadu terytorialnego z perspektywy 25-lecia jego funkcjonowania, red. B. Jaworska-Dębska, R. Budzisz, Warszawa 2016, s. 60.

12 Por. E. Olejniczak-Szałowska, Formy demokracji bezpośredniej w polskim modelu samorzadu terytorialnego (zagadnienia wybrane), [w:] Prawo samorzadowe i administracyjne, red. S. Dolata, Opole 2002, s. 127; R. Szarek, Konsultacje czy referendum, „Wspólnota” 1997, nr 28, s. 22; zob. też wyrok Wojewódzkiego Sądu Administracyjnego w Gliwicach z dnia 18 sierpnia 2016 roku, sygn. IV SA/G1 540/16, LEX nr 2120823.

13 M. Augustyniak, R. Marchaj, op. cit., s. 157. 
Można jednak uznać, że przepis, zgodnie z którym organ stanowiący i kontrolny j.s.t. w toku prac nad projektem uchwały budżetowej nie może usuwać lub zmieniać w stopniu istotnym zadań wybranych w ramach budżetu obywatelskiego stanowi lex specialis w stosunku do niewiążącego charakteru prawnego konsultacji społecznych, których formą jest budżet obywatelski. Z tego względu w doktrynie wyrażono pogląd, zgodnie z którym

budżet obywatelski w formie opisanej w ustawie o samorządzie gminnym jest - w odróżnieniu od konsultacji społecznych — formą demokracji bezpośredniej o charakterze rozstrzygającym. Uzasadnienie dla postawionej tezy znajduje się wprost w treści art. 5a ust. 4 usg, który z mocy prawa każe uwzględnić w uchwale budżetowej zadania wybrane w ramach budżetu obywatelskiego. Dodatkowo, powołany wyżej przepis zabrania radzie gminy w toku prac nad projektem uchwały budżetowej usuwania lub zmieniania w stopniu istotnym zadań wybranych przez mieszkańców ${ }^{14}$.

Mimo wskazywania w piśmiennictwie na wiążący charakter budżetu jako szczególnej formy konsultacji z mieszkańcami oraz sformułowanego w treści przepisu niemożliwości usunięcia przez organ stanowiący i kontrolny jednostki zadań wybranych przez mieszkańców w ramach budżetu obywatelskiego ani też dokonania ich zmiany o charakterze istotnym istnieje jednak ryzyko niewłaściwej interpretacji pojęcia „zmiana istotna”, które poprzez uznanie instytucji budżetu obywatelskiego jako szczególnej formy konsultacji społecznych, niemających przecież charakteru rozstrzygającego dla organów samorządowych, może zostać dodatkowo spotęgowane. Ustawodawca wprost wskazuje bowiem, że budżet obywatelski jest formą konsultacji społecznych, te zaś nie mają wszak charakteru wiążącego dla organów. Dlatego też w celu uniknięcia wątpliwości, które potęguje jeszcze użycie wskazanego zwrotu o charakterze nieostrym, zasadne wydaje się klarowne rozstrzygnięcie kwestii charakteru budżetu obywatelskiego wprost przez ustawodawcę.

Z kolei oparcie charakteru prawnego instytucji budżetu obywatelskiego jako instytucji demokracji bezpośredniej na szczególnej formie konsultacji społecznych ma bardzo istotne znaczenie dla zasięgu podmiotowego zakresu członków społeczności samorządowych, którzy mogą uczestniczyć w wykonywaniu tej formy demokracji bezpośredniej. Zgodnie bowiem z poglądami przyjętymi w judykaturze i piśmiennictwie w procesie konsultacji społecznych mogą brać udział wszyscy członkowie wspólnoty samorządowej, a zatem mieszkańcy danej j.s.t. w rozumieniu k.c. ${ }^{15}$ Odmiennie zatem niż w wypadku legitymacji do udziału w re-

14 Ibidem, s. 160-161.

15 Ustawa z dnia 23 kwietnia 1964 roku Kodeks cywilny, tekst jedn. Dz.U. z 2019 r. poz. 1145. Por. M. Augustyniak, R. Marchaj, op. cit., s. 152 oraz cytowana tam literatura prawa cywilnego; zob. też D. Sześciło, Konsultacje społeczne $w$ gminie $w$ świetle orzecznictwa sądów administracyjnych, „Samorząd Terytorialny” 2014, nr 1-2, s. 29; wyrok Wojewódzkiego Sądu Administracyjnego w Opolu z dnia 13 czerwca 2006 roku, sygn. II SA/Op 213/06, LEX nr 475242; wyrok Wojewódzkiego Sądu Administracyjnego w Gliwicach z dnia 14 stycznia 2014 roku, sygn. I SA/Gl 1291/13, LEX nr 1529502. 
ferendum lokalnym oraz w wyborach w procesie konsultowania budżetu obywatelskiego mogą brać udział będące mieszkańcami j.s.t. osoby niemające pełnej zdolności do czynności prawnych, a więc takie, które nie ukończyły 18 lat lub zostały ubezwłasnowolnione, osoby będące obcokrajowcami, osoby pozbawione praw publicznych prawomocnym wyrokiem sądu oraz osoby niemające zameldowania na terenie jednostki samorządu, w której zamieszkują ${ }^{16}$. $\mathrm{Z}$ tego punktu widzenia ukształtowanie budżetu obywatelskiego jako szczególnej formy konsultacji z mieszkańcami należy poddać pozytywnej ocenie w aspekcie zapewnienia rzeczywistego zwiększania udziału nie tylko obywateli, jak wskazuje tytuł ustawy nowelizującej, lecz wszystkich mieszkańców j.s.t. w procesie funkcjonowania tej jednostki i kontrolowania jej organów, przynajmniej w odniesieniu do budżetu. Ponadto organy jednostki nie są uprawnione do określania kategorii podmiotów uprawnionych do udziału w konsultacjach, a tym samym również w procesie ustalania budżetu obywatelskiego, albowiem

rada gminy nie posiada kompetencji do odbierania komukolwiek prawa do wyrażania opinii w ramach udziału w konsultacjach społecznych, przewidzianych przez postanowienia zawarte $\mathrm{w}$ art. 5a usg. Fakt, iż dana osoba pozbawiona jest praw publicznych, praw wyborczych czy też została ubezwłasnowolniona, nie odbiera jej cechy świadczącej o byciu mieszkańcem gminy, tym samym prawa do udziału w tychże konsultacjach ${ }^{17}$.

Analogiczne rozumowanie należy zastosować w odniesieniu do powiatu i województwa samorządowego oraz wprowadzonej także w tych jednostkach instytucji budżetu obywatelskiego.

W tym kontekście zastosowane przez ustawodawcę określenie „budżet obywatelski” można uznać za zawężające w sposób mylący zakres podmiotowy udziału w tej formie demokracji bezpośredniej. Bardziej adekwatnym określeniem mogłoby zatem być wypracowane w praktyce i doktrynie określenie „budżet partycypacyjny" - oddaje ono bowiem występującą w tym wypadku partycypację wszystkich mieszkańców jednostki, członków jej wspólnoty samorządowej.

16 Por. rozstrzygnięcie nadzorcze Wojewody Zachodniopomorskiego z dnia 30 września 2016 roku, sygn. P-1.4131.223.2016.AB, Dz.Urz. Woj. Zachodniopomorskiego z 2016 r. poz. 3780.

17 Rozstrzygnięcie nadzorcze Wojewody Śląskiego z dnia 29 lipca 2010 roku, sygn. NP/ II/0911/238/10, LEX nr 961641. Zob. też rozstrzygnięcie nadzorcze Wojewody Wielkopolskiego z dnia 29 maja 2017 roku, sygn. KN-I.4131.1.326.2017.3, Dz.Urz. Woj. Wielkopolskiego z 2017 r. poz. 4139; rozstrzygnięcie nadzorcze Wojewody Lubuskiego z dnia 5 czerwca 2014 roku, sygn. NKI.4131.75.2014.Azie, LEX nr 1467199; wyrok Naczelnego Sądu Administracyjnego z dnia 8 grudnia 2011 roku, II OSK 1562/11, LEX nr 1152144; wyrok Wojewódzkiego Sądu Administracyjnego we Wrocławiu z dnia 10 maja 2013 roku, III SA/Wr 140/13, LEX nr 1330077; wyrok Wojewódzkiego Sądu Administracyjnego we Wrocławiu z dnia 24 października 2013 roku, III SA/Wr 654/13, http:// www.lexlege.pl/orzeczenie/125023/iii-sa-wr-654-13-wyrok-wojewodzki-sad-administracyjny-we-wroclawiu (dostęp: 14.09.2020); wyrok Wojewódzkiego Sądu Administracyjnego we Wrocławiu z dnia 27 listopada 2013 roku, III SA/Wr 591/13, https://www.lexlege.pl/orzeczenie/110022/iii-sa-wr-591-13-wyrok-wojewodzki-sad-administracyjny-we-wroclawiu (dostęp: 14.09.2020). 
Należy również zwrócić uwagę na istotne rozwiązanie wpływające na osłabienie udziału mieszkańców w funkcjonowaniu j.s.t. poprzez wykorzystanie instytucji budżetu obywatelskiego. Wiąże się ono z przyjęciem, że w odniesieniu do gmin budżet obywatelski ma zasadniczo charakter fakultatywny, obligatoryjny zaś jedynie w miastach na prawach powiatu. Budżet obywatelski w zależności od wielkości gminy może mieć zatem charakter fakultatywny lub obligatoryjny ${ }^{18}$. Wynika to $\mathrm{z}$ normy prawnej objętej przepisem art. 5 a ust. 5 u.s.g., zgodnie z którym utworzenie budżetu obywatelskiego jest obowiązkowe w gminach będących miastami na prawach powiatu. Jednocześnie w odniesieniu do takich gmin w ustawie zawarto dodatkowe zastrzeżenie dotyczące wysokości budżetu obywatelskiego, która powinna wynosić co najmniej $0,5 \%$ wydatków gminy zawartych w ostatnim przedłożonym sprawozdaniu finansowym. Podobnych rozwiązań prawnych nie zawierają u.s.p. i u.s.w. Powstaje wobec tego pytanie, czy w powiatach i województwach samorządowych budżet obywatelski jest obowiązkową czy też nieobowiązkową formą demokracji bezpośredniej, a tym samym zwiększenia udziału mieszkańców w procesie funkcjonowania i kontrolowania jednostki i jej organów. W świetle przepisów, zgodnie z którymi w ramach budżetu obywatelskiego mieszkańcy w bezpośrednim głosowaniu decydują corocznie o części wydatków budżetu — odpowiednio: powiatu albo województwa — z uwagi na ich kategoryczne brzmienie można by przyjąć, że budżet obywatelski ma charakter obowiązkowy. Przepis zawierający takie samo sformułowanie występuje jednak także w u.s.g. Przepisy te należy uznać za przepisy o charakterze definiującym, określające istotę budżetu obywatelskiego, nie zaś jego obowiązkowy czy dobrowolny charakter. W ustawie gminnej zawarto bowiem dalszy, cytowany już, przepis wyszczególniający obowiązkowe utworzenie budżetu obywatelskiego jedynie w miastach na prawach powiatu. Taki zabieg legislacyjny musi wobec tego oznaczać, że w powiatach i województwach samorządowych budżet obywatelski jako szczególna forma konsultacji społecznych ma charakter nieobowiązkowy, fakultatywny, podobnie jak w gminach niemających statusu miasta na prawach powiatu. Wobec tego konsultacje społeczne w obszarze budżetu obywatelskiego mają charakter obowiązkowy wyłącznie w miastach na prawach powiatu, natomiast w pozostałych j.s.t. — charakter fakultatywny, co może powodować uzależnienie stosowania budżetu obywatelskiego od woli organów tych jednostek, a tym samym osłabienie idei zwiększenia udziału mieszkańców w funkcjonowaniu jednostki i jej organów przez udział w planowaniu jej wydatków na wykonywanie określonych, niejednokrotnie niezwykle istotnych dla mieszkańców lub ich grup, zadań publicznych.

Zgodnie z samorządowymi ustawami ustrojowymi organ stanowiący i kontrolny danej jednostki określa $\mathrm{w}$ drodze uchwały wymagania, które powinien spełnić projekt budżetu obywatelskiego, do których należą w szczególności wymogi

18 M. Augustyniak, R. Marchaj, op. cit., s. 160. 
formalne, jakim powinny odpowiadać zgłaszane projekty, wymagana liczba podpisów mieszkańców popierających projekt, przy czym nie może ona być większa niż $0,1 \%$ mieszkańców terenu objętego pulą budżetu obywatelskiego, w którym zgłaszany jest projekt, zasady oceny zgłoszonych projektów co do ich zgodności z prawem, wykonalności technicznej, spełnienia przez nie wymogów formalnych oraz tryb odwołania od decyzji o niedopuszczeniu projektu do głosowania, zasady przeprowadzania głosowania, ustalania wyników i podawania ich do publicznej wiadomości, biorąc przy tym pod uwagę, że zasady przeprowadzania głosowania muszą zapewniać równość i bezpośredniość głosowania ${ }^{19}$. W literaturze przyjęto, opierając się na poglądach wyrażanych jeszcze przed wprowadzeniem regulacji ustawowej w zakresie budżetu obywatelskiego, że uchwałę w sprawie przeprowadzenia budżetu obywatelskiego należy kwalifikować jako akt prawa miejscowego $^{20}$.

W związku z tym, że — jak uznał ustawodawca — wymagania dotyczące budżetu obywatelskiego powinny zostać określone w każdej j.s.t. w drodze uchwały, mogą one przybrać rozmaity charakter, odmienny w poszczególnych j.s.t. czy kategoriach tych jednostek. Katalog elementów uchwały w sprawie przeprowadzenia budżetu obywatelskiego ma przy tym charakter przykładowy, co powoduje, że konkretna uchwała w tym zakresie może zawierać inne jeszcze elementy. Takie rozwiązanie, z jednej strony, służy zapewnieniu elastyczności i dostosowania do specyfiki danej jednostki. Z drugiej jednak może powodować różny zakres dostępności tej formy udziału w funkcjonowaniu j.s.t. ze strony mieszkańców, uzależniony od przyjętej przez organ stanowiący i kontrolny w konkretnej jednostce wymaganej liczby mieszkańców popierających projekt budżetu obywatelskiego, a tym samym różny zakres jej wykorzystywania w poszczególnych gminach, powiatach i województwach samorządowych.

\section{SPORZĄDZANIE I UTRWALANIE IMIENNEGO WYKAZU GŁOSOWAŃ RADNYCH}

Kolejne rozwiązanie mające na celu zwiększenie udziału mieszkańców j.s.t. w procesie funkcjonowania i kontrolowania organów tych jednostek dotyczy głosowania w organie stanowiącym i kontrolnym każdej z nich i polega na wprowadzeniu obowiązku sporządzania i utrwalania imiennego wykazu głosowań radnych. W świetle art. 14 ust. 2-4 u.s.g., art. 13 ust. 1a-c u.s.p. i art. 19 ust. 1a-c u.s.w. głosowania jawne na sesjach organów stanowiących i kontrolnych odbywają się za pomocą urządzeń umożliwiających sporządzenie i utrwalenie imiennego

19 Art. 5 a ust. 7 u.s.g., art. 3 d ust. 6 u.s.p., art. 10a ust. 6 u.s.w.

20 Zob. R. Marchaj, Charakter prawny uchwaty w sprawie przeprowadzenia budżetu obywatelskiego, „Samorząd Terytorialny” 2017, nr 11, s. 5-14. 
wykazu głosowań radnych. Jeżeli przeprowadzenie głosowania we wskazany sposób nie będzie możliwe, należy przeprowadzić głosowanie imienne. Imienny zaś wykaz głosowań radnych należy niezwłocznie podać do publicznej wiadomości w Biuletynie Informacji Publicznej (dalej: BIP) i na stronie internetowej danej j.s.t. oraz w inny sposób zwyczajowo przyjęty na obszarze tej jednostki.

W każdej j.s.t. wprowadzono zatem wymóg szczególnego rodzaju głosowania imiennego, opierający się na obowiązku wykorzystywania urządzeń umożliwiających sporządzenie i utrwalenie imiennego wykazu głosowań członków organu stanowiącego i kontrolnego, a w przypadku niemożliwości użycia takich urządzeń z przyczyn technicznych — wymóg innego sposobu głosowania imiennego. W literaturze wyrażono pogląd, zgodnie z którym na skutek wprowadzonych zmian de facto każde głosowanie jawne stanie się jednocześnie imiennym, co z kolei musi oznaczać, że normy prawne, w których treści w poprzednim stanie prawnym ustawodawca zastrzegł obowiązek przeprowadzania głosowania imiennego, stają się $\mathrm{w}$ tym zakresie bezprzedmiotowe ${ }^{21}$. Głosowanie jawne imienne jest kwalifikowaną formą zwykłego głosowania jawnego. Podstawowa różnica pomiędzy tymi dwoma trybami głosowania polega na tym, że wyniki głosowania jawnego imiennego zostają udokumentowane w protokole sesji poprzez odnotowanie imienia i nazwiska każdego radnego oraz sposobu, w jaki głosował, to jest czy był za przyjęciem uchwały, czy przeciw, czy też wstrzymał się od głosowania, przy zwykłym zaś głosowaniu jawnym w protokole sesji odnotowuje się jedynie łączną liczbę głosów oddanych „za”, „przeciw” oraz „wstrzymujących się” przy podjęciu uchwały 22 . W moim przekonaniu wprowadzony do ustaw ustrojowych wymóg głosowania jest wymogiem szczególnego rodzaju głosowania jawnego imiennego, które powinno być przeprowadzane przez zastosowanie urządzeń umożliwiających sporządzanie i utrwalanie imiennego sposobu głosowań radnych. Ustawodawca zdecydował więc, że w pierwszej kolejności należy dążyć do przeprowadzania głosowania za pomocą specjalnych urządzeń technicznych, a dopiero w sytuacji, w której ich użycie będzie niemożliwe z przyczyn technicznych, nie zaś jakichkolwiek innych przyczyn, w tym w szczególności decyzji samego organu stanowiącego i kontrolnego o odstąpieniu czy zaniechaniu ich użycia, należy przeprowadzić głosowanie imienne w inny sposób, czyli jak można określić „zwyczajne” głosowanie imienne.

Uwagę zwraca okoliczność, iż wprowadzając wymóg sporządzania i utrwalania imiennych wykazów głosowań radnych w przepisach u.s.w., pozostawiono $\mathrm{w}$ dotychczasowym brzmieniu przepis art. 19 ust. 1 in fine, zgodnie z którym uchwały sejmiku województwa zapadają w głosowaniu jawnym lub jawnym

21 A. Wierzbica, Komentarz do art. 14 ustawy o samorzadzie gminnym, [w:] Ustawa o samorzadzie..., s. 294.

22 Ibidem, s. 292. 
imiennym, chyba że przepisy ustawy stanowią inaczej. Zachowując dotychczasowe brzmienie tego przepisu, ustawodawca dopuścił się wobec tego niekonsekwencji polegającej na wskazaniu alternatywnie na głosowanie jawne (nieimienne) lub jawne imienne, a następnie na wymóg każdorazowego głosowania imiennego szczególnego rodzaju. Podobną uwagę można poczynić w odniesieniu do przypadków głosowania imiennego, jakie występowały do czasu nowelizacji w u.s.g. Wymóg głosowania imiennego w gminie funkcjonował na gruncie art. 28a ust. 5 u.s.g. w odniesieniu do uchwały o przeprowadzeniu referendum w sprawie odwołania wójta (burmistrza, prezydenta miasta) z powodu nieudzielenia mu absolutorium z wykonania budżetu oraz na gruncie art. $28 \mathrm{~b}$ ust. 4 u.s.g. w stosunku do uchwały o przeprowadzeniu referendum w sprawie odwołania wójta (burmistrza, prezydenta miasta) z innej przyczyny niż nieudzielenie mu absolutorium. Przepisy te, podobnie jak treść art. 19 ust. 1 u.s.w., również pozostawiono w dotychczasowym kształcie. Daje to argument przemawiający za postawioną tezą, zgodnie z którą należałoby rozróżniać głosowanie imienne od głosowania za pomocą urządzeń umożliwiających sporządzanie i utrwalanie imiennego sposobu głosowań radnych, które jest szczególnym przypadkiem, szczególnym rodzajem głosowania imiennego.

Ponadto w związku z tym, że przepis art. 14 u.s.g. powinien być traktowany jako lex generalis w stosunku do jej przepisów art. 28a ust. 5 i art. $28 \mathrm{~b}$ ust. 4 , w świetle zaś reguły lex specialis derogat legi generali pierwszeństwo powinny znaleźć ostatnio powołane przepisy, nasuwa się wniosek, że wymóg głosowania imiennego z użyciem urządzeń technicznych umożliwiających sporządzenie i utrwalenie imiennego wykazu głosowań radnych nie obowiązuje w wypadku podejmowania uchwały o przeprowadzeniu referendum $w$ sprawie odwołania wójta z powodu nieudzielenia mu absolutorium z wykonania budżetu i uchwały o przeprowadzeniu referendum w sprawie odwołania wójta $\mathrm{z}$ innej przyczyny niż nieudzielenie mu absolutorium. W świetle tego wystarczające jest w tym przypadku głosowanie imienne przeprowadzone w „zwyczajny” sposób, bez konieczności wykorzystywania urządzeń. Takie rozwiązanie wydaje się z kolei pozostawać w sprzeczności z ideą zwiększenia udziału mieszkańców gminy jako podstawowej j.s.t. w procesie funkcjonowania i kontrolowania jej organów. W celu uniknięcia wskazanych wątpliwości należałoby, moim zdaniem, wykreślić z art. 28a ust. 5 i art. 28 b ust. 4 u.s.g. zwrot dotyczący głosowania imiennego i ewentualnie — dla uniknięcia wątpliwości związanych z brzmieniem tych przepisów sprzed nowelizacji - wprowadzić odwołanie do sposobu głosowania wskazanego w art. 14 ust. 2 i ust. 3 tej ustawy.

Imienny wykaz głosowań należy każdorazowo niezwłocznie opublikować w BIP oraz na stronie internetowej jednostki, a także ogłosić w inny zwyczajowo w jednostce przyjęty sposób. Podkreślenia wymaga, że wskazane trzy sposoby podania głosowania przez poszczególnych radnych do publicznej wiadomości nie mają charakteru rozłącznego i za każdym razem powinny wystąpić łącznie. 
Zauważyć należy, że zastosowane na skutek nowelizacji rozwiązanie rozwiało pojawiające się w praktyce wątpliwości związane z pytaniem, czy rada gminy może samodzielnie decydować o przeprowadzeniu głosowania jawnego imiennego w miejsce zwykłego głosowania jawnego, a w szczególności czy regułę podejmowania uchwał w głosowaniu jawnym imiennym może umieścić w statucie gminy. W doktrynie, orzecznictwie sądów administracyjnych oraz praktyce organów nadzoru przyjmowano, że nie jest to możliwe ze względu na ścisłe określenie przez ustawodawcę przypadków, w których rada gminy powinna stosować głosowanie imienne ${ }^{23}$, i nieposłużenie się analogicznym rozwiązaniem jak to, które wynika z cytowanego wcześniej art. 19 ust. 1 u.s.w. ${ }^{24}$

\section{TRANSMITOWANIE I UTRWALANIE OBRAD ORGANÓW STANOWIĄCYCH I KONTROLNYCH J.S.T.}

Nowelizacja wprowadziła także wynikający z treści obecnych przepisów art. 20 ust. 1a u.s.g., art. 15 ust. 1a u.s.p. i art. 21 ust. 1a u.s.w. obowiązek transmitowania i utrwalania obrad organów stanowiących i kontrolnych j.s.t. za pomocą urządzeń rejestrujących obraz i dźwięk, a następnie udostępniania tych nagrań w BIP i na stronie internetowej jednostki oraz w inny zwyczajowo przyjęty sposób. Usankcjonowano zatem przyjętą już w niektórych j.s.t., w tym normowaną w niektórych ich statutach, choć jednak nie powszechnie, praktykę utrwalania przebiegu obrad za pomocą urządzeń rejestrujących dźwięk, a niekiedy także obraz ${ }^{25}$. Wprowadzenie przedmiotowego obowiązku należy uznać nie tylko za dążenie do poszerzenia zasady jawności działania organów j.s.t. ${ }^{26}$, lecz także przyczynienia się do zwiększenia udziału mieszkańców poszczególnych jednostek w procesie funkcjonowania oraz kontrolowania ich organów stanowiących i kontrolnych. W każdej bowiem takiej jednostce każdorazowe utrwalanie i transmitowanie obrad jej organu stanowiącego i kontrolnego, w odniesieniu zarówno do dźwięku, jak i obrazu, następnie zaś publikowanie sporządzonych nagrań w BIP, na stronie internetowej jednostki, a także w inny sposób zwyczajowo przyjęty stało się obligatoryjne. Ustawodawca przewidział więc trzy sposoby publikacji nagrań, które powinny być stosowane łącznie. W związku z ostatnim z nich w piśmiennictwie zgłoszono postulat dotyczący rady gminy, z którym należy się zgodzić i który

23 Wskazanych w art. $28 \mathrm{a}$ ust. 5 i art. $28 \mathrm{~b}$ ust. 4 u.s.g.

24 M. Cyrankiewcz, Głosowanie imienne, „Wspólnota” 2007, nr 3, s. 28; zob. też rozstrzygnięcie nadzorcze Wojewody Kujawsko-Pomorskiego z dnia 19 stycznia 2017 roku, Dz.Urz. Woj. Kujawsko-Pomorskiego z 2017 r. poz. 390; wyrok Wojewódzkiego Sądu Administracyjnego w Lublinie z dnia 8 marca 2016 roku, sygn. III SA/Lu 1366/15, CBOSA.

25 T. Moll, Komentarz do art. 20 ustawy o samorzadzie gminnym, [w:] Ustawa o samorzadzie..., s. 367.

26 Por. ibidem. 
można rozciągnąć również na organy stanowiące i kontrolne pozostałych jednostek, dotyczący konieczności unormowania zasad dostępu do utrwalanych nagrań posiedzeń tych organów w regulacjach statutowych. Skoro bowiem przepis wskazuje na konieczność udostępniania nagrań także w sposób zwyczajowo przyjęty, to przepisy statutu powinny ten sposób wskazywać. Praktyka w tym względzie może być wszakże odmienna $\mathrm{w}$ różnych j.s.t. i w związku z tym „praktykę tę należy usankcjonować"27.

Można się zastanawiać, czy zawarty w drugim zdaniu powołanych przepisów zwrot „,nagrania obrad” odnoszący się do obowiązku ich publikacji dotyczy zarówno nagrań dźwięku, jak i obrazu. Z punktu widzenia realizacji celu nowelizacji odpowiedź powinna być twierdząca, choć nie jest to oczywiste na podstawie brzmienia przepisów.

Wątpliwości na gruncie analizowanych regulacji dotyczą także kwestii, czy chodzi w nich o bezpośrednią transmisję obrad w tak zwanym czasie rzeczywistym, czy też jedynie o utrwalanie dźwięku i obrazu z przebiegu obrad i przekazywanie ich do elektronicznej bazy danych internetowych oraz do BIP. W literaturze wskazano w tym zakresie na obowiązek prowadzenia bezpośredniej transmisji, a przy tym na to, że przepisy zapewniają możliwość późniejszego, wielokrotnego odtwarzania przebiegu obrad bez jakichkolwiek ograniczeń czasowych ${ }^{28}$. W takiej sytuacji może powstać dalsza wątpliwość, czy nadal zasadne będzie utrwalanie przebiegu obrad w formie tradycyjnego pisemnego protokołu. Na dziś należy stwierdzić, że wobec wyraźnego obowiązku udostępniania protokołów z posiedzeń organów j.s.t. oraz komisji organów stanowiących i kontrolnych, objętego przepisami art. 11 b ust. 2 u.s.g., art. 8 ast. 2 u.s.p. i art. 15a ust. 2 u.s.w., wciąż istnieje konieczność sporządzania pisemnego protokołu z przebiegu obrad organów stanowiących i kontrolnych ${ }^{29}$. Obowiązek utrwalania obrad za pomocą urządzeń rejestrujących dzwięk i obraz istnieje więc niezależnie od obowiązku sporządzania pisemnego protokołu z przebiegu obrad.

Jakkolwiek idea zapewniania mieszkańcom większego udziału w procesie funkcjonowania i kontrolowania organów j.s.t. pozostaje słuszna, to należy mieć na względzie, że wprowadzenie obowiązku transmisji i rejestracji przebiegu obrad organów stanowiących i kontrolnych wiąże się z koniecznością zakupu przez każdą j.s.t. odpowiednich urządzeń elektronicznych. W szczególności dla gmin, zwłaszcza tych niewielkich, może to stanowić wydatek, który przekroczy ich możliwości finansowe. Aby zapobiec temu zjawisku, ustawodawca stworzył radom gmin oraz radom powiatów możliwość zawierania porozumień z Szefem Krajowego Biura Wyborczego w sprawie zasad korzystania w tym celu z urządzeń wykorzystywanych podczas wyborów do utrwalania czynności obwodowych komisji

\footnotetext{
27 Zob. ibidem, s. 368.

28 Ibidem, s. 367.

29 Ibidem, s. 368.
} 
wyborczych ${ }^{30}$. Przewidujące to rozwiązanie przepisy art. 20 ust. 1c u.s.g. i art. 15 ust. 1 b u.s.p. zostały jednak uchylone ustawą z dnia 15 czerwca 2018 roku o zmianie ustawy - Kodeks wyborczy oraz niektórych innych ustaw ${ }^{31}$, która weszła w życie 20 lipca 2018 roku. Tym samym gminy i powiaty utraciły możliwość wykorzystywania urządzeń służących do utrwalania czynności komisji wyborczych i stanęly przed koniecznością obligatoryjnego zaopatrzenia się w stosowne urządzenia na własny koszt. Można się wobec tego zastanawiać, czy analizowane rozwiązanie służące zwiększeniu udziału mieszkańców w procesie funkcjonowania i kontrolowania organów samorządowych pozostaje proporcjonalne do tego celu, w szczególności biorąc pod uwagę okoliczność, że w praktyce niewielka liczba mieszkańców może przejawiać zainteresowanie odtwarzaniem nagrań z przebiegu obrad organu stanowiącego i kontrolnego zamieszkiwanej przez nich j.s.t.

\section{PODSUMOWANIE}

W uzasadnieniu projektu ustawy nowelizującej z 11 stycznia 2018 roku wskazano między innymi, że

wnioskodawcy proponują zmiany, które realnie przyczynią się do zapewnienia społeczności lokalnej większego udziału w funkcjonowaniu organów danej jednostki samorządu terytorialnego, pochodzącej z aktu wyboru, oraz zagwarantują obywatelom właściwą kontrolę nad władzą samorządową, a tym samym przyczynią się do zwiększenia więzi oraz odpowiedzialności za wspólnotę samorządową, w której zamieszkują ${ }^{32}$.

Z punktu widzenia podmiotu samorządu terytorialnego, który tworzą wszyscy mieszkańcy danego obszaru, określonego terytorium ujętego w jednostkę samorządu terytorialnego, bez względu w szczególności na ich obywatelstwo, w wątpliwość podać jednak można już sam tytuł ustawy nowelizującej, jak też stosowne rozwiązania mające służyć celom sformułowanym w jej uzasadnieniu.

Będące przedmiotem analizy dokonanej w niniejszym artykule rozwiązania zastosowane przez ustawodawcę $\mathrm{w}$ nowelizacji ustrojowych ustaw samorządowych mogą wzbudzać zastrzeżenia, po pierwsze, z punktu widzenia ich przyczynienia się do realizacji zamierzonych celów, co można odnieść do zasadniczo fakultatywnego charakteru budżetu partycypacyjnego, do zastosowania określenia o charakterze nieostrym, które w praktyce może wpłynąć na możliwość eliminowania przez organy j.s.t. zadań wskazanych do realizacji przez mieszkańców w ramach instytucji budżetu, czy wreszcie do możliwości kształtowania restryk-

30 Zob. ibidem.

31 Dz.U. z 2018 r. poz. 1349.

32 Uzasadnienie do poselskiego projektu ustawy o zmianie niektórych ustaw w celu zwiększenia udziału obywateli w procesie wybierania, funkcjonowania i kontrolowania niektórych organów publicznych, druk nr 2001 Sejmu VIII kadencji. 
cyjnych wymogów koniecznych do spełnienia w celu przedłożenia przez mieszkańców przedmiotowego budżetu, co wynika z zapewnienia znacznej elastyczności w ich ustalaniu w poszczególnych j.s.t. Po drugie, w toku oceny analizowanych instytucji można wskazać również na wątpliwości odnoszące się do ich relacji z innymi dotychczas funkcjonującymi rozwiązaniami, co ma miejsce w odniesieniu do wprowadzenia szczególnego rodzaju głosowania imiennego, które powinno być przeprowadzane przy użyciu urządzeń umożliwiających sporządzenie i utrwalenie imiennego wykazu głosowań radnych, czy wreszcie do ich proporcjonalności do zamierzonego celu. Mając bowiem na uwadze nakłady finansowe, jakie j.s.t. będą zmuszone ponieść na nabycie takich urządzeń, a także urządzeń służących do spełnienia wymogu transmitowania i utrwalania obrad organów stanowiących i kontrolnych, zarówno w odniesieniu do obrazu, jak i dźwięku, można się zastanawiać, czy nie należałoby uznać za wystarczające wprowadzenia jako obligatoryjnego „Zwyczajnego" głosowania imiennego, tym bardziej że i tak zachowany zostaje obowiązek sporządzania z przebiegu obrad, a zatem i głosowania, tradycyjnego pisemnego protokołu, który objęty jest obowiązkiem jawności działania każdej j.s.t. W stosunku zaś do transmisji obrad organów należałoby zadać praktyczne pytanie, mianowicie czy będą one przedmiotem zainteresowania ze strony mieszkańców, a przynajmniej ich znaczącej części.

THE CIVIL BUDGET, OBLIGATION TO PREPARE A WRITTEN LIST OF COUNCILLORS' VOTES, OBLIGATION OF BROADCASTING AND RECORDING OF THE MEETINGS OF STATUTORY AND CONTROL BODIES AS INDICATIONS OF INCREASED PARTICIPATION OF MEMBERS OF LOCAL SELF-GOVERNMENT COMMUNITIES IN THE PROCESS OF FUNCTIONING AND CONTROLLING LOCAL SELF-GOVERNMENT BODIES IN THE LIGHT OF THE AMENDMENT OF LOCAL SELF-GOVERNMENT STATUTORY ACTS OF 11TH JANUARY 2018

Summary

One of the goals of the amendment of local self-government statutory acts, which was introduced by the Act of 11th January 2018, was the increase in participation of citizens (members of local self-government communities) in the process of functioning and controlling local self-government bodies. In the article an analysis is made of the provisions establishing the institutions of the civil budget, the obligation to prepare a written list of councillors' votes, the obligation of broadcasting and recording of the meetings of statutory and control bodies and an attempt has been made to assess the implementation through these institutions of the objectives set by the authors of the amendments.

Keywords: civil budget, obligation to prepare a written list of councillors' votes, obligation of broadcasting and recording of the meetings of statutory and control bodies, process of the functioning and controlling local self-government bodies 


\section{BIBLIOGRAFIA}

Augustyniak M., Marchaj R., Komentarz do art. 5 a ustawy o samorządzie gminnym, [w:] Ustawa o samorzadzie gminnym. Komentarz, red. B. Dolnicki, Warszawa 2018.

Baraniecki M., O swoich pieniądzach decydujemy sami — planowanie partycypacyjne budżetu gminy, [w:] Partycypacja społeczna w samorzadzie terytorialnym, red. B. Dolnicki, Warszawa 2014.

Cyrankiewcz M., Gtosowanie imienne, „Wspólnota” 2007, nr 3.

Dąmbska A., Mieszkańcy na tym nie skorzystaja, „Dziennik Gazeta Prawna” 2018, nr 44.

Jaworska-Dębska B., Normatywne podstawy społecznego dialogu w samorządzie terytorialnym, [w:] Prawne problemy samorzadu terytorialnego z perspektywy 25-lecia jego funkcjonowania, red. B. Jaworska-Dębska, R. Budzisz, Warszawa 2016.

Marchaj R., Charakter prawny uchwaty w sprawie przeprowadzenia budżetu obywatelskiego, „Samorząd Terytorialny" 2017, nr 11.

Martysz C., Komentarz do art. 28aa ustawy o samorzadzie gminnym, [w:] Ustawa o samorzadzie gminnym. Komentarz, red. B. Dolnicki, Warszawa 2018.

Moll T., Komentarz do art. 20 ustawy o samorzadzie gminnym, [w:] Ustawa o samorzadzie gminnym. Komentarz, red. B. Dolnicki, Warszawa 2018.

Olejniczak-Szałowska E., Formy demokracji bezpośredniej w polskim modelu samorzadu terytorialnego (zagadnienia wybrane), [w:] Prawo samorzadowe i administracyjne, red. S. Dolata, Opole 2002.

Szarek R., Konsultacje czy referendum, „Wspólnota” 1997, nr 28.

Sześciło D., Konsultacje społeczne w gminie w świetle orzecznictwa sądów administracyjnych, „Samorząd Terytorialny" 2014, nr 1-2.

Sześciło D., Uwarunkowania prawne budżetu partycypacyjnego w Polsce, „Finanse Komunalne” 2012, nr 12.

Wierzbica A., Komentarz do art. 14 ustawy o samorzadzie gminnym, [w:] Ustawa o samorzadzie gminnym. Komentarz, red. B. Dolnicki, Warszawa 2018. 